\title{
Cutaneous Leishmaniasis, trends of the disease in Koya city, during
} 2015 to 2018

\author{
Maysoon Omar Nasraddin(1) Rukhosh Eshaq Mekha(2) \\ Mehri Mirhaj M.salh(3) Azhi Aram Kareem(4)
}

\author{
Mehri Mirhaj Muhammadsalih \\ Koya Technical Institute/Erbil Polytechnique University, Koya/ Erbil / Iraq \\ mehri.salih@epu.edu.iq
}

Rowkhoshm@gmail.com

\begin{abstract}
Cutaneous leishmaniasis is not an endemic disease in the Kurdistan region of Iraq, particularly not in Erbil governorate and Koya city. Due to internal conflicts and immigration of people ( from Syria and other parts of Iraq) to the Kurdistan region, the disease has now been reported in koya city among internally displaced persons and military personnel (peshmarga) so, the present study aims to assess the prevalence rate of cutaneous lieshmaniasis in Koya city within 2015-2018.

This descriptive-analytical study has been conducted on the victims of cutaneous leishmaniasis during previous years in health centers of Koya city, by extracting the demographic and epidemiologic information of study sample, recorded in Koya health centers, as well as analyzing this data into the patient's age, gender, place of residence, ethnicity, infected body organ and infection season. The total incidence rate was reported 79 cases within 2015 to 2018 in which 71 (89.9\%) were males and 8 (10.1\%) were females. The highest total incidence rate of the disease was in the age range 30 39 of $34 \%$ and the lowest one in the age range above 50. Most damages (wounds) were observed in the hands and feet. Moreover, the some of the patients had more than one wounds. The highest incidence rate of the disease was reported in autumn and the least one in winter.
\end{abstract}

As the study results revealed, disease prevalence rate has been increased in Koya city during 2015-2018 that is because of war, which can indicate in appropriate hygiene 
practices by the people during this time of war. However, the number show decline in the end shows improvement in educational-hygienic status.

Keywords: Cutaneous leishmaniasis, educational-hygienic status, demographic and epidemiologic information.

\section{INTRODUCTION}

Leishmaniasis is a disease caused by an intracellular parasite, which is transmitted to humans by the bite of infected female phlebotomine sandflies. The disease has three main forms: cutaneous leishmaniasis (CL), mucocutaneous leishmaniasis, and visceral leishmaniasis, depending on the species of Leishmania parasite involved and the immune response of the host .( Torres-Guerrero et al, 2017).

According to the World Health Organization (WHO), leishmaniasis is one of the seven most important tropical diseases and it represents a serious world health problem that presents a broad spectrum of clinical manifestations with a potentially fatal outcome (Andrade et al, 2001).

Cutaneous Leishmaniasis (CL) remains a major world health problem in the 21st century (Hepburn, 2003). Every year about 0.5 to 2 million new cases are identified (Clem, 2012).

The causative agents are blood and tissue dwelling intracellular protozoan parasite species belonging to the genus Leishmania. Infection with leishmania specie could result in disease condition ranging from chronic but often self-healing skin lesions, cutaneous leishmaniasis $(\mathrm{CL})$, to erosive mucosal membrane destruction of the nasopharynx known as mucocutaneous leishmaniasis, and a life-threatening systemic infection with hepatospleenomegly in visceral leishmaniasis. The nature and extent of the disease is determined by complex interactions between the infecting species of Leishmania and the immunological status of the host (Hoyos et al, 2016).

Although the disease has been described from parts of 88 countries in the tropics and sub-tropics where some 350 million are at risk of infection. The epidemic of leishmaniasis has been associated with deforestation, road construction, wars, or other activities where humans intrude the habitat of the vector (WHO, 2016). 


\section{Problem statement}

Currently there are 12 million victims of Leishmaniasis in the world. Humans can be infected by the sting of female sand fly (phlebotomus),

In Iraq, leishmaniasis was facing extinction but starting ISIS war at $2015 \mathrm{~L}$. major zoonotic cutaneous leishmaniasis cases appear again. Leishmaniasis has been increasingly appeared in most cases lesions are located on the limbs. In case of outbreaks, lesions are large and multiple. However, in Kurdistan the number of cases were very limited. The cases mostly appear among Peshmarga during their duties in Kirkuk. In Koya city it is been an increase in the number of cases of leishmaniasis among Peshmarga, refuge people and refugee camps.

\section{Objective}

Objective of the study are to assess the prevalence of cutaneous leishmaniasis in koya city within 215-2018, determine the impact of the war on the health status and identify the incidence rate with putting plan for prevention strategies. 


\section{MATERIAL AND METHODS}

\section{Setting of the study}

This observational, descriptive study was conducted on the cutaneous leishmaniasis victims who had visited health centers and lab clinics of Koya city.

The study was conducted within 2015-2018. The required information was extracted from Information Record System of General Directorate of Health in Koya city such as the patient's age sex, place of residence, ethnicity, infected body organ and infection season.

\section{Sample and diagnostic procedures}

Seventy nine patients with clinically diagnosed Cutaneous leishmaniasis from both sexes and different ages were included in this study. They were attended health centers and lab clinics of Koya city within 2015-2018, samples were obtained only from those sites which showed the most indurated margin. For patients exhibiting more than one lesion, a detailed examination of each lesion was performed in order to choose the site of sample extraction. The lesion was cleaned of debris with saline solution. Purulent or necrotic ulcers were treated with particular care, and debris was removed. None of the patients had received any anti-leishmanial chemotherapy treatment prior to diagnostic examination. Samples for parasitologic diagnosis included dermal scraping of the active indurated margins of the lesions, dermal scraping of the bottoms of the ulcers, and fine needle aspirate for culture (Ramirez, 2000).

The slides of scraping materials were air dried, fixed with methanol, and stained with Giemsa. The slides were analyzed with a 100X immersion objective and examined by the same person.

\section{RESULT AND DISCUSSION}

The present study was conducted on 79 positive cases of cutaneous leishmaniasis within 2015-2018 (the majority of cases were peshmerga or combat forces), our data showed variable results in the frequency of $C L$ in recent years. during the current years of this study, the most victims of the disease was observed in 2016 of 32 cases, whereas 
in 2015 the rates differed to 21 cases, and in 2017 of 20 cases were reported. Finally in 2018 till now 6 cases have been reported.

The present study noticed that the highest prevalence of CL was in 2016 then, 2015. Its known that our region is not endemic of the disease because of absent the vector, but these outbreaks cases of CL related to the emigration event in different region of the state. The war of terrorist and military operation which correlated with emigration may be consider as a main causes of the prevalence of disease (Abdulla et al,2018). These findings were supported by another study in Iraq (Abdulla et al ,2018).

The results in the present study cleared that incidence of $C L$ decreased in the frequency after 2017 because of limiting emigration event, decreasing the war and also due to other factors including, demonstrating an improvement in educational-hygienic status as well as people's following of hygiene practice.

In the current study, $89.9 \%$ of the victims were males and $10.1 \%$, were females and the incidence rate of disease was higher among men than women.According to the study years, the most victims of the disease was observed in 2016 of 32 cases and all of them were male, whereas in 2015 the rates changed to 21 cases of $66.7 \%$ male and $33.3 \%$ female, and in 2017 of $20,95 \%$ and $5 \%$ were reported for male and female patients respectively. Finally, in 2018 till three months before now cases have been reported and all of the cases were males as summarized in (table 1).

Table.1: Incidence rate of cutaneous leishmaniasis cases based on victims' gender

From the period (2015-2018).

\begin{tabular}{llllll}
\hline Gender & 2015 & 2016 & 2017 & 2018 & Total \\
\hline Male & 14 & 32 & 19 & 6 & 71 \\
\hline Female & 7 & 0 & 1 & 0 & 8 \\
\hline Total & 21 & 32 & 20 & 6 & 79 \\
\hline
\end{tabular}




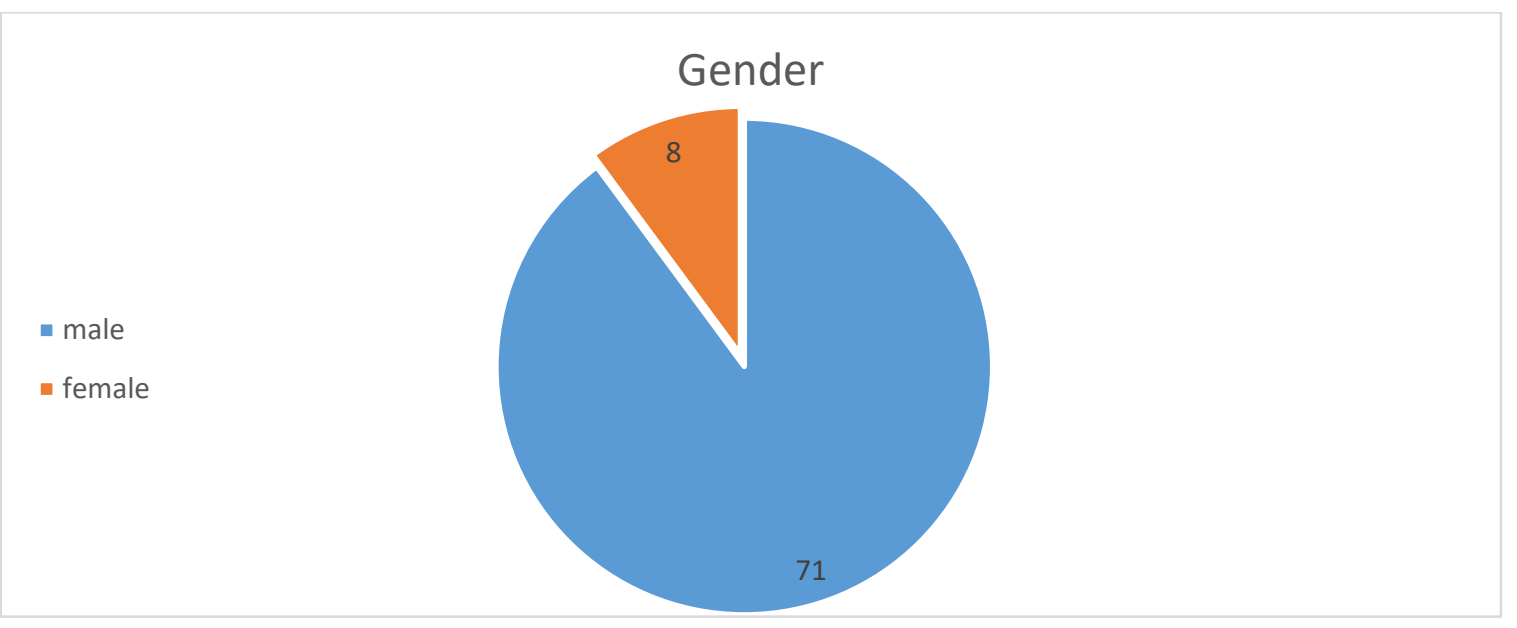

Fig.1: Prevalence rate of cutaneous leishmaniasis infection based on victims' Gender.

The high rate in male as this study indicated was consistent with previously reported studies ( AlSamarai, and AlObaidi, 2009. ),( Rahman, 2009),(Kumar, 2007), (Rastogi and Nirwan,2007), (Stewart,2009), (Alsamari et al,2016) and (Rahi ,2013) .

The high incidence of cases in males than female may be attributed to that males are more exposed to sand fly than female due to their outdoor work or men stay more outside home because of their job (Alzaki, 2014), ( Rahman, 2009) and (Kumar, 2007). Although it is believed that the establishment and the course of parasitic diseases may influenced by sex hormones and behavioral factors, making male individuals more likely to be exposed to vectors in fields and other transmission environments (Rastogi and Nirwan,2007), (Stewart,2009).

Similar to another study in which done in Erbil (Abdulla et al ,2018), most of the males in our report were Peshmarga, they were infected in the time of their duties. ,this high proportion of infection among them could be due to their occupations, less immunity, less clothing, hot weather of the region, and exposure to sand flies.

The results in the current study was not agreement with other studies that found the higher incidence of infection among females than males (Akcali et al,2007) and ( Alzaidawi,1997). 
Table 2: Prevalence rate of cutaneous leishmaniasis infection based on victims' age for the period (2015-2018).

\begin{tabular}{llllll}
\hline & $\mathbf{2 0 1 5}$ & $\mathbf{2 0 1 6}$ & $\mathbf{2 0 1 7}$ & $\mathbf{2 0 1 8}$ & Total \\
\hline Birth-9 & 7 & 3 & 0 & 0 & 10 \\
\hline $\mathbf{1 0 - 1 9}$ & 5 & 0 & 0 & 0 & 5 \\
\hline $\mathbf{2 0 - 2 9}$ & 4 & 5 & 5 & 0 & 14 \\
\hline $\mathbf{3 0 - 3 9}$ & 3 & 12 & 7 & 5 & 27 \\
\hline $\mathbf{4 0 - 4 9}$ & 1 & 10 & 7 & 1 & 19 \\
\hline Above 50 & 1 & 2 & 1 & 0 & 4 \\
\hline Total & 21 & 32 & 20 & 6 & 79 \\
\end{tabular}

This table showed the highest total incidence rate of the disease was observed in the age range of 30-39 years of 27 cases (34.2\%), then and the lowest one in the age above 50 years of 4 cases (5.1\%), although , the study found that the incidence of CL in all age groups but with different rates according to the study years..

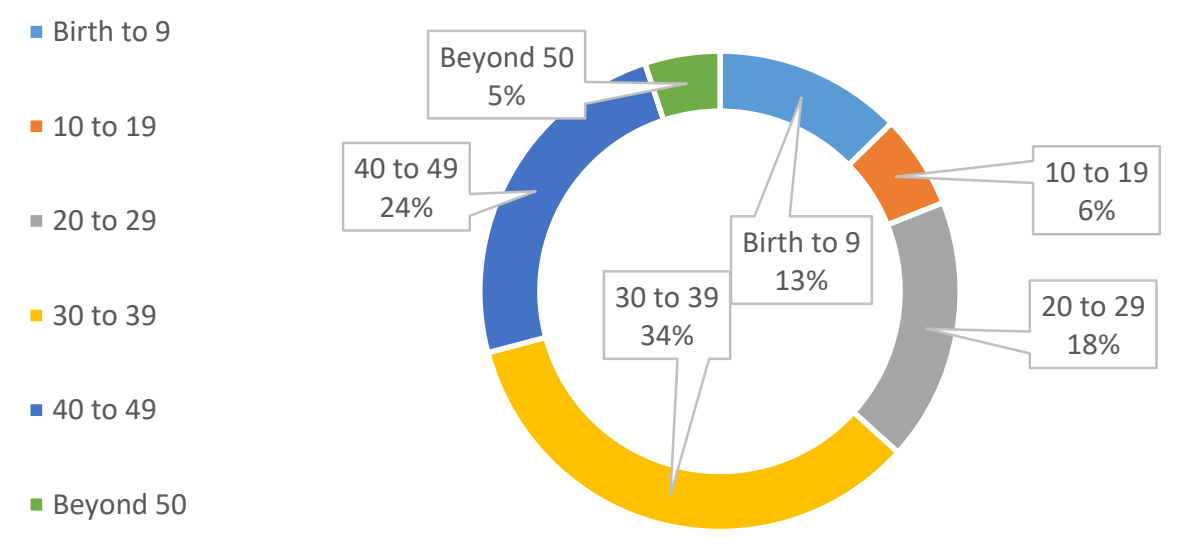

FIG. 2: represent the number of cases based on age 
The high frequency of disease in the age group (30-39),(40-49) and(20-29) respectively because the individuals in these age ranges may travel more frequently than younger ones to endemic areas; they also constitute most of the military forces and farm workers( Hamzavi and Khadami, 2015). Younger and older people may stay indoors more and consequently they are less likely to be bitten by the vector (Al-zaidawi,1997).

This result was in agreement with previous reports (indicating these ages were more exposure as a result of educational and occupational situations).( AISamarai, and AlObaidi, 2009) and (Al-Obaidi, 2016).

Regarding to distribution of CL lesions or with inflected body organs in this study, we found that the higher proportion of the lesions were located on the upper and lower limbs $(65 \%)$, face (31\%) and less frequently on the other organ (2\%) as presented in (table 3).

In comparison, the study by (AL-Obaidi, 2016) found that CL lesions occurred mainly on upper limbs and lower limbs, less frequently on the face, and much less frequently on the trunk. These observations contrast those of (Al-Zaidawi, 1997) who reported that the face was most affected. However, the results showed some patients suffering from multiple site of infection and infected organ. and result could be due to long periods of exposure to Plebotomine sand flies and the high population density of sand flies in this area.

The vector attack exposed areas of the body to suck blood; thus the lesions most frequently appear on the hands, face and legs. The differences in distribution of lesions noted in the studies mentioned above may be explained by the living conditions and habits of the people concerned. For example, some people prefer to sleep outdoors, thus exposing their upper and lower limbs as well as their faces to sand fly bites at night when the insects become more active. In general, the presence and distribution of lesions depend on which parts of the body are exposed and on the susceptibility of the host (AL-Obaidi, 2016).

Similar to other studies the incidence of the $C L$ in this study was higher in rural than in urban areas. In Saudi Arabia (Haouas et al, 2015) and in Turkey [Tahanoglu et al, 2014], but in contrast with other study in Erbil (Al-Zaidawi, 1997) indicated that, the incidence 
rate of disease was higher in urban areas compared with rural related to the fact that most Peshmargas are from rural areas and a role for human subjects in spreading CL cannot be confirmed because of the lack of information about the type of Leishmania parasite also the type of sandflies in the affected areas.

The current study cleared higher incidence rate of CL in Autumn and reached a maximum rate $75 \%$ then starts to decline from summer and reaches the lowest level in winter. This finding agrees with the findings reported by AL-Obiadi in Iraq, but not with those reported from Iran [Muqbil and Mubel, 2016].. The differences in seasonal and/or regional variation in incidence could be due to variation in distribution and bionomic of sand flies Climate changes as in (table 3 ).

Table 3: Prevalence rate of cutaneous leishmaniasis victims based on the infected organ, place of residence, and the infection season.

\begin{tabular}{|c|c|c|c|c|c|c|}
\hline \multirow[t]{4}{*}{ Infected organ } & & 2015 & 2016 & 2017 & 2018 & Total \\
\hline & Face & 9 & 8 & 7 & 1 & 25 \\
\hline & Hands and feet & 12 & 22 & 13 & 5 & 52 \\
\hline & Other organ & 0 & 2 & 0 & 0 & 2 \\
\hline \multicolumn{2}{|l|}{ Total } & 21 & 32 & 20 & 6 & 79 \\
\hline \multirow{2}{*}{$\begin{array}{l}\text { place of } \\
\text { incidence }\end{array}$} & Urban & 8 & 10 & 5 & 3 & 26 \\
\hline & Rural & 13 & 22 & 15 & 3 & 53 \\
\hline \multicolumn{2}{|l|}{ Total } & 21 & 32 & 20 & 6 & 79 \\
\hline \multirow{4}{*}{$\begin{array}{l}\text { Time of } \\
\text { infection } \\
\text { (season) }\end{array}$} & Spring & 0 & 2 & 2 & 0 & 4 \\
\hline & Summer & 4 & 7 & 3 & 0 & 14 \\
\hline & Autumn & 17 & 22 & 15 & 6 & 60 \\
\hline & Winter & 0 & 1 & 0 & 0 & 1 \\
\hline \multicolumn{2}{|l|}{ Total } & 21 & 32 & 20 & 6 & 79 \\
\hline
\end{tabular}

This table indicate that the highest incidence rate in current study occur among Peshmarga of 60 cases compare to civil people of 19 cases. In regard to ethnicity 68 of cases were Kurdish people while 11 cases were Arabic people. Figure 3 shows some leishmaniasis victims that taken by the health center in koya city. 

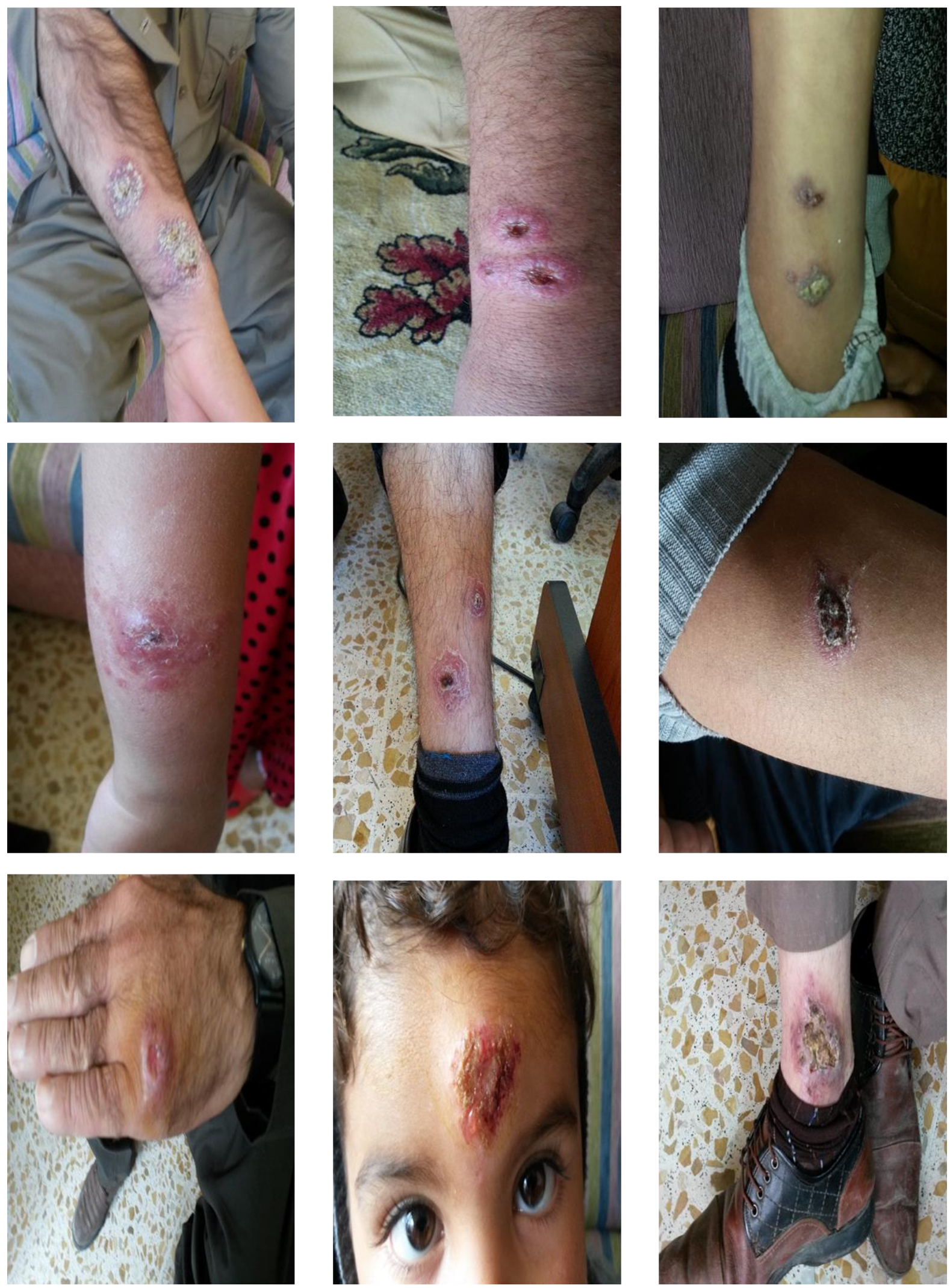

Figure (3): represents victims of cutaneous leishmaniasis in koya city 


\section{Conclusion}

Based on the current study cutaneous leishmaniasis is a serious health problem in Koya city. On the basis of the distribution of the disease from 2015 to 2018, it can be concluded that the war has direct effect on increasing the cases numbers of leishmaniasis. It is also concludes that the disease activity based on seasons and geographic status. Personal hygiene can eliminate the disease.

\section{Recommendations}

Based on the results of the study, numerous recommendations should be considered in endemic area:-

1. Raising awareness regarding this disease is a vital component of prevention in the endemic area

2. Bed nets should be provide and educational programs should be done to all the peshmerga that who have a duty in the endemic area regarding communicable disease especially CL.

3. Eliminate the vectors and reduce the spread of infection.

4. Providing treatment in positive case to eliminating the transmission.

\section{References}


1. Abdulla QB , Shabila NP and Al-Hadithi TS (2018) An outbreak of cutaneous leishmaniasis in Erbil governorate of Iraqi Kurdistan Region in 2015. J Infect Dev Ctries 2018; 12(8):600-607. doi:10.3855/jidc.10306.

2. Akcali C, Culha G, Inaloz HS (2011) Cutaneous leishmaniasis in Hatay. J Turk Acad Dermatol 1: 1-5.

3. Al-Obaidi MJ, Abdulhusain MY, Al-Saqur IM (2016) Survey study on the prevalence of cutaneous leishmaniasis in Iraq. Iraqi J Sci 57: 2181-2187. 18

4. Al-Obaidi MJ, Abdulhusain MY, Al-Saqur IM (2016) Survey study on the prevalence of cutaneous leishmaniasis in Iraq. Iraqi J Sci 57: 2181-2187.

5. Alsamarai AM, Ahmed Alobaidi AH, Aljumaili ZK, Jasim MM, Qatal S (2016) Cutaneous Leishmaniasis in Iraq: A Continuing Endemic Disease. J Drug Des Res 3(1): 1024.

6. AISamarai AM, AlObaidi HS (2009) Cutaneous leishmaniasis in Iraq. J Infect Dev Ctries 3: 123-129. DOI: https://doi.org/10.3855/jidc.59

7. AISamarai, A.M. and AlObaidi, H.S., 2009. Cutaneous leishmaniasis in Iraq. The Journal of Infection in Developing Countries, 3(02), pp.123-129.

8. AL-Zaidawi KA (1997) New approach for treatment of cutaneous leishmaniasis by manitol. Diploma dissertation, College of Medicine, University of Tikrit, Iraq.

9. Andrade-Narváez FJ, Vargas-González A, Canto-Lara SB, et al:: Clinical picture of cutaneous leishmaniases due to Leishmania (Leishmania) mexicana in the Yucatan peninsula, Mexico. Mem Inst Oswaldo Cruz. 2001; 96(2): 163-7.

10. Clem,A. (2012). Current perspectiveon the Leishmaniaiasis. J. Glob. Infect. Dis. 2:142126.

11. Hamzavi \& Khademi( 2015) Trend of Cutaneous Leishmaniasis in Kermanshah Province, West of Iran from 1990 To 2012. Iran J Parasitol: Vol. 10, No. 1,, pp.7886.

12. Haouas N, Amer O, Ishankyty A, Alazmi A, Ishankyty I (2015) Profile geographical distribution of reported cutaneous leishmaniasis cases in Northwestern Saudi Arabia from 20102013. Asian Pac J Trop Dis 8: 287-291.

13. Hoyos CL, Cajal SP, Juarez M, et al.: Epidemiology of American Tegumentary Leishmaniasis and Trypanosoma cruzi Infection in the Northwestern Argentina. Biomed Res Int. 2016; 2016: 6456031.

14. Kumar R, Bumb RA, Ansari N, and Metha R(2007) Cutaneous leish-maniasis caused by L. tropica in Bikaner, India:Parasite identification and characterization 
using molecular and immunologic tools. Am J Trop Med Hyg. , 2007; 76(5): 896901.

15. Mubil NA, Muqbel AM (2016) Cutaneous leishmaniasis in Al-Sawalha area, Lahj governorate, Yemen. Micromedicine 4: 37-42. 25

16. Rahi AA (2013) Cutaneous Leishmaniasis in Iraq: A clinicoepidemiological descriptive study. Sch. J. App. Med. Sci., 2013; 1(6):1021-1025 College of Science / Wasit University, Iraq.

17. Rahman SF, Ghulam M, Pathan PA (2009) A survey of cutaneous leishmaniasis at village Gaibidero, district Larkana, Sindh, Pakistan .J. Gomal Med. Sci., (7): 2.

18. Ramirez JR, Agudelo S, Muskus C, et al. (2000) Diagnosis of cutaneous leishmaniasis in Colombia: the sampling site within lesions influences the sensitivity of parasitologic diagnosis. J Clin Microbiol 38:3768-3773.

19. Rastogi V, Nirwan $P(2007)$ Cutaneous leishmaniasis: an emerging infection in anonendemic area and abrief update. Indian J Med Microbiol., 2007; 25:272-275.

20. Stewart CC, Brieger WR (2009) Community views on cutaneous leishmaniasis in Istalif, Afghanistan: implications for treatment and prevention. Int Quart Commun Health Education; 29: 123-142.

21. Torres-Guerrero E, Quintanilla-Cedillo MR, Ruiz-Esmenjaud J, Arenas R (2017) Leishmaniasis: a review. F1000Res 6:750.

22. Torres-Guerrero E, Quintanilla-Cedillo MR, Ruiz-Esmenjaud J, Arenas R (2017) Leishmaniasis: a review. F1000Res 6:750.

23. Turhanoglu M, Alperdal S, Bayindir BF (2014) A nine-year evaluation of cutaneous leishmaniasis patients in Diyarbakir training and research hospital, Turkey. Mikrobiyol Bul 48: 335-340.

24. World Health Organization: Weekly Epidemiological Record (WER). 2016; 91(22): 285-296.

25. Zakai HA.(2014) Cutaneous leishmaniasis in saudia Arabia, current status. J.ADV Lab Res Bio. 4:20-34.

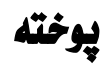




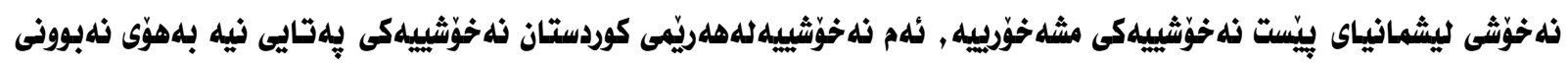

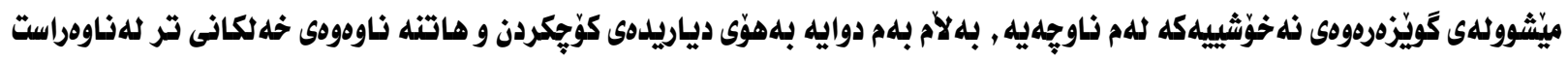

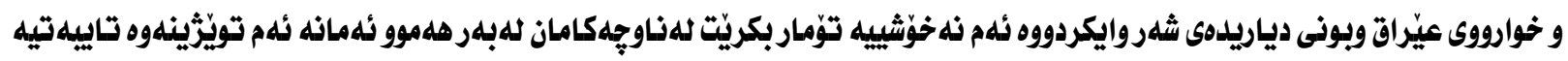

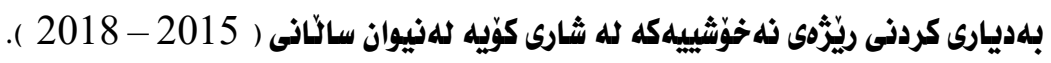

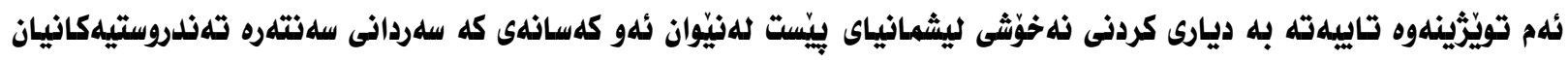
كردووه للهشارى كوَيه للهم ماوديهدا.

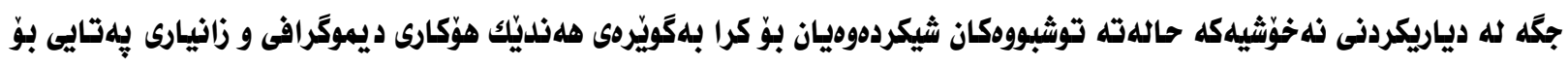

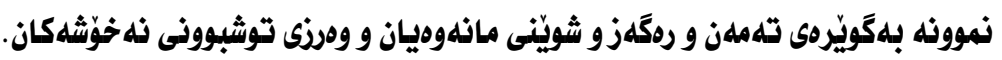

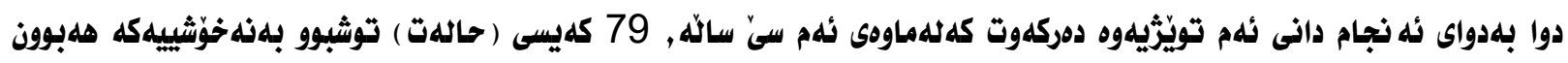

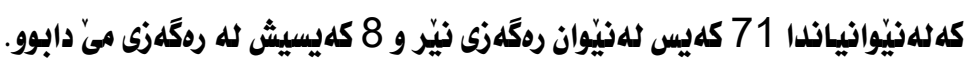

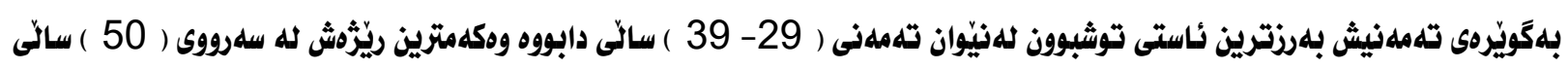
دابووه.

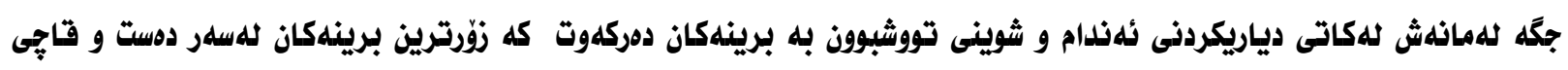

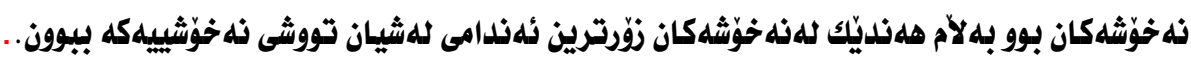

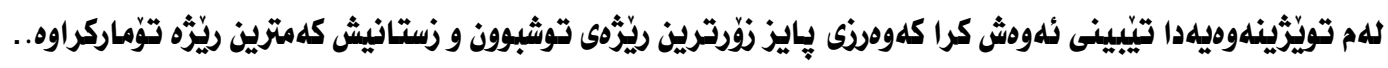

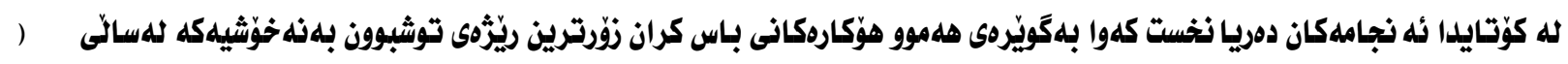

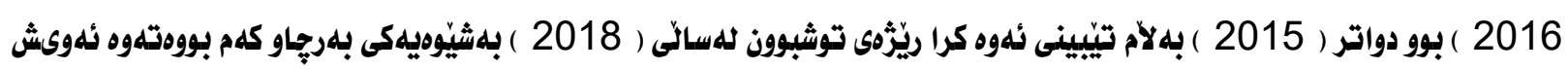

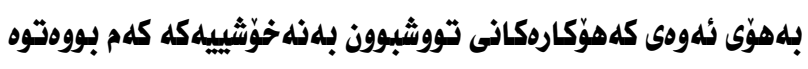

\section{الخلاصة}


ان مرض ليشمانيا الجلدية هو من الامراض غير الوبائية فى ا قليم كوردستان ومحافظة اربيل ,خاصة" في قضاء كويسنجق,

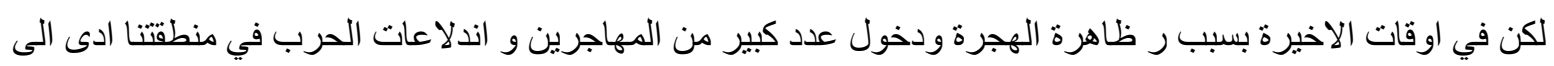

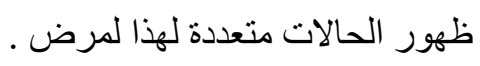

في هذه الدر اسة حاولنا ان نحدد حالات المرض ونسبة انتشار الاصابة بين الاشخاص الذين زارو المر اكز الصحية في مدينة كويسنجق بين الاعو ام ( 2015 - 2018.

اضافة" لغرض تحديد حالات الاصابة تم تحليل النتائج حسب الخصائص الديمو غر افية لعينة الدراسة مثل ( العمر ر الجنس , مكان الاقامة وحسب فصول السنة)

بعد الانتهاء من الدر اسة وحسب النتائج حددنا على وجود (79) حالة اصابة ولاحظنا ان هنالك ( 71 ) حالة اصابة بين الرجال و

( 8 ( 8 ) حالات بين النساء فقط.

و سجلت الفئة العمرية (29- 39) اعلى نسبة اصابة وا قل حالات الاصابة للفئة العمرية اعلى من ( 50 ) سنة, و لاحظناوجود اغلب حالات المرض فى اليدين والاقدام وكذلك وجدنا حالات تعددد الجروح على اعضاء مختلفة للمصابين. اظهرت الدر اسة ان اغلب الحالات حدثت فى فصل الخريف و اقلها فى الثتاء.

كما تبيين ان انتشار الاصابة كان الاكثر فى سنة ( 2016 ) و اقلها في سنة (2018 ) وذللك بسبب انخفاض العوامل المسببة للمرض . 